\title{
O romance possível - ensaísmo e narração em $O$ homem sem qualidades, de Robert Musil ÉRICA GONÇALVES DE CASTRO I
}

"Não que amassem a todos que viam e a tudo o que acontecia:
apenas sentiam a linda sobra do 'como seria' caindo sobre seus corações..." (R. Musil. O homem sem qualidades $)^{1}$

\section{"Um admirável monumento em ruínas"}

\section{"A} HISTÓRIA desse romance é aquela que deveria ser contada nele, mas não o será" - com essas palavras o escritor austríaco Robert Musil procurava apresentar, numa entrevista (Musil, 1978b, p.939-40) o tema de seu romance $O$ homem sem qualidades, obra cuja elaboração estendeu-se por mais de trinta anos, e que permaneceu inacabada. Os primeiros esboços datam de meados da década de 1910, o primeiro volume foi publicado em 1930 e o segundo, sob insistência do editor, dois anos mais tarde, ainda inacabado. Cerca de cinco mil páginas manuscritas, entre material publicado, variantes de capítulos e anotações foram sendo acumuladas ao longo dos anos, formando o arcabouço de uma obra cuja elaboração se tornava cada vez mais complexa. Na fatídica manhã de 1942, quando sofre um ataque fulminante em seu exílio na Suíça, Musil ainda havia trabalhado no capítulo "Suspiros de um dia de verão", um dos principais daquela que seria a terceira e última parte do romance. ${ }^{2}$

Uma vez que é próprio da forma romanesca que esta se constitua no processo mesmo de sua criação, o Homem sem qualidades assume um caráter exemplar nesse sentido, pois suas componentes narrativas estão longe de ser simples. Aliás, seu tema, ainda que desenvolvido numa linguagem clássica, é justamente a inviabilidade da épica tradicional no mundo moderno. O protagonista Ulrich é alguém que reconhece a incapacidade de atribuir um "sentido épico primitivo” (Musil, 2006, p.689) à sua existência. Ora, se o conteúdo de um romance, como diz a célebre formulação de Lukács, "é a história de uma alma que sai a campo para conhecer a si mesma" (2000, p.91), o que esperar de uma narrativa na qual o conflito do herói consista na perda do "fio narrativo" de sua vida, na busca por uma outra forma de vida, mais legítima, dentro dos limites impostos pela realidade empírica? Esse complexo projeto romanesco tinha por tarefa responder a duas questões fundamentais: como o homem moderno deve se com- 
portar espiritualmente em relação à realidade e qual seria o romance possível naquele mundo entreguerras, onde a literatura não podia mais atribuir à vida uma causalidade da qual ela mesma não é capaz (Musil, 1978b). A tentativa de resposta desdobra-se na figura de Ulrich: o homem sem qualidades predeterminadas, disposto a viver como personagem de um livro, e porta-voz da "utopia do ensaísmo". Difundida no e pelo romance, essa utopia pretende pôr em movimento o princípio fundamental da literatura, e da arte em geral: a ampliação das possibilidades, o contato com mundos possíveis, a partir da realidade empírica. O ensaísmo, característica central da poética musiliana, assume em O homem sem qualidades um duplo papel: é tanto um procedimento formal, já que a obra se caracteriza pela associação orgânica entre narrativa romanesca e digressão ensaística, como também princípio de vida propagado pelo protagonista.

Ao assumir o desafio de adotar a forma romanesca para narrar uma aventura intelectual, a obra parece ter sido, desde o início, destinada ao inacabamento. Mas o esforço de Musil em representar, com a maior amplitude possível, o homem moderno em sua dicotomia essencial - "capaz da mais elevada exatidão e da mais extrema dissolução" (Blanchot, 1986, p.196) -, torna O homem sem qualidades uma obra de fato interminável, "um admirável monumento em ruínas” (ibidem, p.184), mas com linhas de força muito bem definidas, que apontam com toda clareza para a catástrofe eminente. Tendo vivido nos anos dourados da monarquia habsburga e testemunhado sua derrocada, Musil se reconhecia como parte de uma geração de intelectuais que, diante do colapso de todo um sistema de valores, tinha a chance de moldar uma cultura autêntica, apropriada à vida na modernidade e na civilização tecnológica. ${ }^{3}$ Ele via no romance uma forma de intervenção na realidade muito mais eficaz do que as ciências ou a filosofia - que, segundo ele, não estariam devidamente habilitadas para o desafio de superar a alienação e a inércia predominantes. Não se tratava, contudo, de opor a literatura à ciência, mas, antes, de concebê-las como complementares; Musil tinha a clara convicção de que era preciso superar a ideia corrente de que existem duas formas opostas de conhecimento, para que os métodos e práticas das ciências exatas pudessem ser transpostos para domínios mais “inexatos”, como o do sentimento e do espírito. Somente dessa forma seria possível uma reflexão sobre os fenômenos que não excluísse a esfera subjetiva.

Uma vez que a criação poética não tem o compromisso de representar o que é, mas sim o que deve ser, o escritor exerce sua racionalidade no domínio da ética, isto é, do indeterminado e do incalculado. Sua missão é "descobrir constelações, novas variantes, construir modelos atrativos para o homem; enfim, criar o homem interior" (Musil, 1978b, p.1029). O que o homem vive e experimenta depende, porém, de condições exteriores; esse "homem interior" a ser criado é, portanto, aquele que vislumbra formas de vida que não as familiares, ou as da realidade efetiva. Cabe à literatura imaginar uma tal forma, suscitando condições de transformação da experiência humana - e não apenas de descrevê-las ou representá-las com a pretensão de forjar uma realidade explicada. ${ }^{4}$ Já se 
tornaram lapidares as reflexões de Adorno acerca do narrador do romance contemporâneo: este não pode mais pretender dizer algo de excepcional, "como se o curso do mundo ainda fosse essencialmente um processo de individuação, como se o indivíduo, com suas emoções e sentimentos, ainda fosse capaz de se aproximar da fatalidade, como se seu íntimo ainda pudesse alcançar algo por si mesmo" (Adorno, 2003 , p.56-7). Pois é interessante observar que numa conferência proferida cerca de vinte anos antes - "O escritor nos dias de hoje", de 1934) - Musil (1978b, p.1243-70) já desenvolvia reflexões análogas: segundo ele, o romance contemporâneo não podia mais focalizar apenas "destinos individuais" (ibidem, p.1248) porque, àquela altura da história, o indivíduo passara a ser apenas mais um elemento num grande todo, e suas forças morais teriam se tornado muito frágeis em relação ao mundo que o cerca, de modo que a literatura não podia correr o risco de "reforçar seu enquadramento" nessa ordem opressora (ibidem, p.1246). Seria preciso, pois, encontrar um caminho que mostrasse o sujeito como parte de um todo e, ao mesmo tempo, acenasse com a possibilidade de uma desvinculação dessa mesma ordem. Essa terceira possibilidade, em que "novas constelações" se fundam, em que "as esferas interior e exterior condicionam-se mutuamente" (ibidem, p.1249) é o programa que uma obra como $O$ homem sem qualidades pretende cumprir, ao subordinar a narração de eventos - ou a representação de situações e personagens num contexto específico - à narração de uma aventura intelectual de um herói que tenta escapar dos perigos da razão moderna.

Nesse sentido, Musil compõe o entorno de seu protagonista como um campo de forças que, através do entrelaçamento das partes reflexivas e narrativas, reproduz o ritmo autêntico da experiência humana, transformando o "fio da épica” em seu próprio tema. Não se trata, contudo, de uma associação direta entre realidade empírica representada e reflexão, uma vez que as passagens de cunho estritamente ensaístico não pretendem encontrar no mundo dos eventos o endosso daquilo que tematizam. Se, por um lado, O homem sem qualidades dissolve as categorias narrativas de tempo, ação e espaço, colocando-as em questão, ou decompõe intencionalmente as situações narrativas clássicas; por outro, o texto dispõe de um narrador autoral, que usa toda a amplitude de suas possibilidades de representação, numa linguagem que se coloca acima do relato, dispondo de diferentes formas de distância, que renovam continuamente a narração como médium. "Desta forma, a própria narração já demostra os diferentes procedimentos gnosiológicos que, ao mesmo tempo, ela tematiza explicitamente: a forma narrativa e a reflexão sobre suas possibilidades não se separam” (Renner, 1989, p.125). O movimento que anima a obra, portanto, é o mesmo da reflexão ensaística, em que as ideias se sobrepõem umas às outras, sem intenção de atingir uma síntese. E, assim, uma nova forma de narrar surge justamente do cerne daquilo que parecia inviabilizar por completo o papel da narração: não se trata mais de descrever fatos reais ou que poderiam sê-lo, mas de explorar possibilidades. Ao abrir mão de uma estrutura épica tradicional em 
favor de um estilo ensaístico, o romance de Musil visa representar as condições de assimilação da realidade por um indivíduo sensível e disposto a "amar todas as manifestações da vida" (Musil, 2006, p.79). Em um mundo em que nada é sólido ou definitivo, o indivíduo hesita em agir e em fazer escolhas, só restando-lhe ser um homem sem qualidades.

\section{Qualidades e possibilidades}

Protótipo do herói clássico burguês, Ulrich terá seu sobrenome omitido, nos adverte o narrador, em respeito à figura de seu pai, um eminente advogado com "um talento aristocrático de uma altivez quase inconsciente" (Musil, 2006, p.33). Tal recurso, característico dos primeiros romances realistas, é empregado com o intuito de causar no leitor a impressão de que uma história está em curso, e de que esse herói viverá uma sequência de "aventuras". Trata-se, contudo, de uma personagem que pretende retirar-se da ação. Definindo-se como um homem "sem qualidades", no sentido de ser privado dos atributos que ordinariamente conferem ao eu moderno o que se convencionou chamar de "existência" - profissão, família, círculos sociais -, Ulrich decide tirar "férias da vida" justamente a fim de descobrir o sentido da sua.

Uma das poucas "qualidades" que o narrador atribui ao protagonista é a de ser uma "mente viril", um "ser pensante". Isso the garante a "capacidade de pensar tudo aquilo que também poderia ser" (Musil, 2006, p.34), atribuindo o mesmo valor ao real e ao possível. A constatação de sua falta de qualidades - ou de características próprias, como indica claramente o sentido da palavra alemã Eigenschaft ${ }^{5}$ - e um senso aguçado para as possibilidades o levam a formular as utopias do ensaísmo e da exatidão. Estas, por sua vez, serão o caminho de acesso à sua grande utopia, a do "outro estado", que será tema do segundo volume do romance. Essas duas utopias representam dois aspectos fundamentais do projeto musiliano. Poderia consistir em um paradoxo pensarmos que a ideia de ensaio, ligada ao caráter provisório e fragmentado do pensamento, esteja associada à de exatidão. Mas vale lembrar que, se essas mesmas ideias são concebidas como utopias, é porque cabe a elas formar uma dualidade que, para Musil, seria a chave para o "ser em potencial", aquele que fica suspenso entre os dois polos: não se desvincula do real ao mesmo tempo em que não se deixa cercear por seus limites. Além de representarem a complementaridade entre literatura e ciência reivindicada pelo autor, ambas as utopias são concebidas como uma "quase" possibilidade.

Utopias significam mais ou menos o mesmo que possibilidades; o fato de a possibilidade não ser realidade significa que as circunstâncias com as quais se entrelaça atualmente a impedem de se tornar real, caso contrário ela seria apenas uma impossibilidade; se a soltarmos dessas amarras, e permitirmos que se desenvolva, surgirá a utopia. (Musil, 2006, p.273)

Desde seu momento inaugural no âmbito da Era moderna, em Thomas Morus, a utopia se constitui como uma tentativa de preencher uma falta. Ela 
carrega, ao mesmo tempo, um princípio de negação e de construção, pois apenas o processo de negação da realidade constituída permite uma construção racional passível de transformá-la (Vobkamp, 1990, p.24ss). Assim, se por um lado o senso de possibilidade difundido pelo romance tem a pretensão de ultrapassar os limites da realidade; por outro, este não pode ignorá-la - afinal, é nela que estão contidas as possibilidades. Para Wiegmann (1978 p.310-11), a noção musiliana de utopia é mais abrangente do que a de possibilidade justamente porque se insere no campo da literatura, e não da realidade mesma. Sendo originariamente um não lugar (U-topos), a utopia se converte assim em uma zona intermediária, o lugar do possível, onde as "amarras" da realidade podem ser rompidas; enfim, o lugar da literatura. No entanto, a literatura sempre corre o risco de reduzir as possibilidades contidas na realidade ao pretender imitá-la. A obra literária é uma via de acesso a um conhecimento que não depende de uma elaboração conceitual, mas que acontece como uma parábola. Sendo um recorte, o conhecimento que ela gera será necessariamente limitado em comparação às ambições da ciência. Ao ser introduzido no seio do romance como seu princípio formal, o ensaísmo será o medium que possibilita reescrituras da experiência que não se subordinam à lógica causal e que, portanto, ampliam o potencial gnosiológico da literatura. Enquanto personagem, Ulrich será palco de um experimento que procura aproximar a arte da ciência. Sua postura ensaística se constitui, na verdade, como uma experimentação em sentido pleno: ao suspender o mundo para melhor conhecê-lo, ele enfim se dá conta de que a realidade é apenas uma forma de realização, entre outras possíveis:

[...] nenhuma coisa, nenhum eu, nenhuma forma, nenhum princípio é certo, tudo se encontra numa transformação invisível e incessante, no instável há mais futuro do que no estável, e o presente não é senão uma hipótese que ainda não superamos. O que [Ulrich] poderia fazer de melhor senão manter-se livre desse mundo, naquele bom sentido com que um pesquisador se mantém livre diante dos fatos que o querem seduzir e fazer acreditar neles precipitadamente?! (Musil, 2006, p.277)

A exatidão será, paradoxalmente, o reconhecimento da imprecisão dos fatos e da impossibilidade de verdades definitivas. Quando associada ao espírito ensaístico, promove a convivência entre os âmbitos objetivo e subjetivo, sem que um se sobreponha ao outro, de modo que, no seio da obra, funda-se um campo intermediário entre pensamento e alma, ou ciência e arte.

\section{O “eterno artifício" da épica}

Sendo a realidade uma utopia, a representação da história como uma sucessão lógica e linear não passa de um artifício que obedece à necessidade humana de solidez e segurança. Nesse sentido, o romance apresenta também o mundo dos eventos, mas, antes, visando revelá-lo como eterno retorno, como um mundo em que "sempre acontece a mesma coisa" ("Seinesgleichen geschieht", título da segunda parte do livro). As referências espaçotemporais são bastante 
escassas ao longo do romance, mas é possível saber que o enredo se situa em Viena, entre os anos 1913 e 1914. Dentre os episódios que confrontam Ulrich com a realidade, os mais relevantes são o processo de julgamento do carpinteiro Moosbrugger - um indivíduo perturbado mentalmente, que assassina a facadas uma prostituta que o assediou - e as reuniões em torno da "Ação paralela", na qual Ulrich, a pedido de seu pai, é admitido como secretário. Espécie de síntese cultural da elite vienense da época, a "Ação" reúne os espíritos dotados das melhores "qualidades", empenhados na organização de um grande evento comemorativo do septuagésimo jubileu do império habsburgo, que aconteceria no ano de 1918. A motivação não é apenas celebrar os valores e as glórias imperiais, mas também fazer frente ao evento que a Prússia vinha preparando para o trigésimo jubileu do reinado de Wilhelm II, previsto para o mesmo ano. Basta a notícia da ação prussiana para que a elite vienense se empenhe em encontrar uma ideia fulgurante, que fizesse jus a uma monarquia muito mais longeva e de proporções mais gigantescas que a prussiana.

Será a partir do entrecruzamento dos perfis e dos discursos pretensiosos e vazios dessas personagens que Ulrich percebe sua solidão, e passa a adotar uma postura mais reservada. Assim como a ação é "paralela", sua participação no comitê também será: ele assume, antes, a posição de um espião - não por acaso um dos primeiros títulos pensados por Musil - que a de secretário, mas não com o objetivo de contribuir para o malogro da "Ação"; na verdade, ele participa dessas reuniões menos por obediência à imposição paterna do que como um meio de (auto)conhecimento, na posição de livre observador - ou como um pesquisador que precisa guardar certa distância do objeto que pretende analisar.

O nome escolhido para a "ação" assume no romance uma conotação triplamente irônica: ela pode ser considerada paralela tanto em relação ao evento original prussiano quanto às digressões ensaísticas do romance, mas, acima de tudo, porque não levará a parte alguma - pois em 1918, ambas as monarquias já não existirão mais. Além disso, tal como no princípio geométrico, todos os seus membros, embora situados no mesmo plano - a intenção de celebrar o mundo imperial -, não possuem um ponto comum que, em algum momento, poderá uni-los. Os perfis dos membros da "Ação", assim como as demais personagens que gravitam em torno de Ulrich nesse primeiro volume, buscam atingir um equilíbrio precário ao se vincularem a papéis sociais ou a causas ideológicas, mas, absorvidos em seu interesses individuais, são incapazes de se unirem em torno um mesmo um ideal ou de perceber a eminência de uma catástrofe, e representam, cada um a seu modo, “as variantes mentais de uma época doente, em que pulsavam os diferentes avatares do idealismo" (Wolf, 2011, p.104). E ainda que o tom satírico predomine nessas passagens, elas assumem, na constituição geral do romance, um sentido "veladamente dramático", como observa Blanchot (1986, p.187): pois não é apenas o valor da cultura austríaca que é colocado em xeque, mas o da cultura como um todo, reduzida a um refinamento estéril que "se desdobra gloriosamente no vazio contra o qual ela nos protege ao tentar dissimulá-lo". 
Em contraponto a essa sociedade presa a valores já sem sentido, Musil introduz a figura do rústico carpinteiro Moosbrugger. Antes instintivo do que racional, é de sua natureza alternar estados de loucura, realidade e sonho. Num primeiro momento, essa personagem parece representar a barbárie oculta por trás da máscara de civilidade da sociedade burguesa; no entanto, sua condenação capital pelo assassinato de uma prostituta que o abordara durante sua solitária caminhada noturna é apenas mais um dos vértices da confusão de valores que o romance busca tematizar. Esse ser nada convencional precisa ser "objetivado" perante a opinião pública porque sua existência representa um impasse: nem a liberdade, nem a prisão e nem o hospício parecem soluções plausíveis; juristas, religiosos e médicos fracassam na tentativa de encontrar uma terminologia adequada para seu comportamento. Ulrich verá a sala do tribunal como um "retrato da vida": é o hábito de "racionalizar tudo o que está a seu alcance" que faz que os jurados, refletindo a opinião pública, optem pela solução que lhes parece a mais plausível, também porque é a única que conhecem, ou por serem incapazes de pensar na "possibilidade de agir de outra maneira" (Musil, 2006, p.275), ainda que a própria realidade lhes ofereça situações atípicas que possibilitaria "contar uma outra história". ${ }^{6}$

E justamente esse ser privado da capacidade de se comunicar de forma convencional ou inteligível para aqueles que o julgam será o representante da psique coletiva: "Se a humanidade pudesse sonhar como um todo, então teria de surgir Moosbrugger" (Musil, 2006, p.96). Sem a mediação do intelecto, ele percebe o mundo de modo mais instintivo e imediato, e sem dominar a linguagem instrumental, ele passa a senti-la como dominadora. É inconcebível para a sociedade que o condena ver seu crime como um ato de legítima defesa, uma agressão que, na verdade, foi uma tentativa de restabelecimento da ordem predominante em seu mundo: o silêncio, bruscamente rompido pelas palavras da moça. Seu ato instintivo corresponde, no plano da Ação paralela, à inclinação - silenciosa - de seus membros para a guerra.

A insatisfação com o presente e o anseio de superá-lo é o que todas as personagens têm em comum. No entanto, o que a "Ação" busca no plano coletivo, Moosbrugger e Ulrich, cada um a seu modo, buscam no plano individual. A despeito de suas capacidades intelectuais distintas, ambos se sentem isolados em relação a uma ordem onde nada lhes parece firme ou verdadeiro. Moosbrugger, na verdade, representa uma potenciação do sentimento de falta de qualidades de Ulrich. Na leitura de Albertsen (1997, p.89ss), trata-se de dois "homens sem qualidades", e o primeiro o é no "modo indicativo", pois possui e vivencia todas as qualidades ao mesmo tempo, enquanto o segundo é privado de qualidades no "modo subjuntivo", porque sabe que poderia assumir qualquer qualidade que quisesse, optando por permanecer em suspenso. Por isso os pensamentos de Ulrich sempre o conduzem a um sentimento paradoxal de, ao ansiar por uma unidade, constatar o quanto está distante desta. Em sua existência "subjuntiva", porém, ele não empunha uma faca, mas engaja-se numa apreensão ensaística do mundo. 
A presença de um enredo desenvolvido paralelamente às passagens ensaísticas permite considerar o romance de Musil como "realista", no sentido de uma intencionalidade - ou seja, o autor "adota a realidade como ponto de partida; mas não a trata como passível de ser retratada, e sim como um porvir, uma instância a ser constituída" (Honold, 1995, p.72ss). Assim, as referências espaçotemporais são bastante diluídas no texto, numa "ausência sintomática" (ibidem) que pretende excluir a realidade para torná-la ainda mais evidente. Ao encenar o alheamento predominante - sobretudo na "elite pensante"-o romance evidencia o sintoma mais imediato de um prejuízo em relação ao sentimento do tempo, e que também atingirá o leitor: o desafio de identificar vestígios da guerra ou da Viena da virada do século na constituição da obra reproduz, de certa forma, a dificuldade de se orientar na organização da vida moderna, a partir das novas condições de percepção que esta mesma impõe. Assim, o romance não pretende oferecer uma descrição autêntica da realidade histórica, como adverte o próprio narrador: "nem aqui nem mais adiante, faremos a duvidosa tentativa de pintar um quadro histórico e competir com a realidade" (Musil, 2006, p.194, grifos meus). Trata-se, antes, de fazer que essa realidade se reflita na mentalidade de um ser ordinário.

Quando começa a projetar o livro, Musil chega a cogitar fazer de seu herói um escritor. A hipótese logo é abandonada, como para que deixar livre o campo de atuação de Ulrich e de suas descobertas. ${ }^{7}$ Ainda que versado em disciplinas de diferentes áreas, Ulrich tem de ser um homem comum, para que as premissas da existência e da literatura possam coincidir. O problema da fabulação épica do escritor corresponde ao conflito existencial da personagem porque, no bojo de ambos, está o ocaso da experiência e a perplexidade diante de um processo crescente de "abstração da vida". No fim da primeira parte, o pressuposto de composição da obra se converte na grande revelação de Ulrich: a de ter perdido o "fio narrativo" da própria existência - essa necessidade de "enfileiramento de tudo que acontece no tempo e no espaço" (Musil. 2006, p.689), que não é apenas uma convenção literária.

[...] o leitor sente-se confortável, e isso seria difícil de entender, se esse eterno artifício da obra épica, com o qual já as amas-de-leite acalmavam as criancinhas, esse eficiente "encurtamento em perspectiva da razão" já não fizesse parte da própria vida [...] [os homens] preferem a sequência ordenada dos fatos, porque parece necessária, e, com isso, a impressão de que suas vidas têm um "curso" protege-os de alguma forma no caos. (ibidem)

Para Musil, não é o valor da narração em si que está em xeque, mas, antes, a possibilidade de atribuir "uma sequência ordenada" aos eventos. A articulação entre intelecto e sentimento, entre elementos ensaísticos e narrativos, reproduz, necessariamente, o ritmo autêntico dos fenômenos da realidade efetiva, que não é, de modo algum, linear. Dentro de uma realidade que é a realização momentânea de uma história entre outras possíveis, toda empresa humana será um ensaio e toda existência, um poema - ou romance - a ser escrito. E para alguém que 
tem a ambição de viver como personagem de um livro, somente uma imagem pode restituir um pouco de sentido perdido. É através desse recurso literário que Ulrich experimenta uma restituição momentânea do "fio narrativo" de sua existência - o que não se dá por meio de um encadeamento épico, mas por uma "lógica deslizante" (Musil, 2006, p.631) própria do ensaio. Esse processo acontece quando o protagonista reconhece a existência de dois estados humanos, violência e amor, que sempre são falsamente relacionados. A percepção de que sua vida sempre se cindira entre esses dois princípios será condensada na imagem das duas "árvores da vida”, "duas trilhas, uma sob a luz do dia, outra fechada na escuridão [...] que ele jamais conseguira reunir" (ibidem).$^{8} \mathrm{E}$, assim, Ulrich transpõe para o terreno muito determinado de sua existência terrena o princípio mesmo da narrativa primordial: a parábola das duas árvores que, se não lhe restitui o fio épico, ao menos acena com algum sentido: “essas múltiplas relações do ser humano consigo mesmo e com a natureza, que ainda não são puramente objetivas e talvez nunca o sejam, só se podem conceber como parábolas [Gleichnisse]" (ibidem). ${ }^{9}$

Dessa "compreensão intacta" de sua vida interior surge em Ulrich um desejo de ação de "influir na realidade", mas não com a frieza de um analista, e sim com uma "paixão evidente e implacável” (ibidem) - enfim, uma disposição de espírito ensaística, e que associa violência e amor. "Violência” é o nome para a atitude das pessoas dentro da realidade, pois manifesta claramente a intenção de fixar os eventos e organizá-los num sistema. Por sua vez, o amor se refere a uma outra forma de experiência, ainda não vivida, sentida de modo nostálgico, ou de um modo "outro"; enfim, um estado que só pode ser vivenciado como um vislumbre. Uma vez que o princípio do amor visa um sentido além do habitual, ele faz parte do mundo das possibilidades, de uma lógica que não obedece à razão, mas que nem por isso é privada de sentido. E agora a associação entre existência e literatura atinge um novo patamar, pois a própria personagem percebe a importância da formulação imagética na constituição do sujeito: uma imagem é expressão de um outro, mas esse outro é sua verdade e seu significado; nela, o sentido surge de forma multívoca e simultânea, não se cristalizando num conceito. A semelhança promovida pela imagem não corresponde a uma lógica usual; ela é, antes, “aquela ligação de ideias que reina no sonho, a deslizante lógica da alma, à qual corresponde o parentesco das coisas nas intuições da arte e da religião" (ibidem, grifos nossos).

“A alma 'desliza' porque jamais uma fórmula, seja uma lei científica, uma regra moral ou um termo linguístico é capaz de prever a transformação que atinge o universal por meio do individual" (Frank, 1985, p.112). Com a imagem das duas árvores da vida, o primeiro volume já alude ao sentido maior da experiência do outro estado. O reconhecimento dos dois princípios e da incapacidade de atribuir um fio à sua vida não significa uma resposta às questões de Ulrich, apenas uma transformação de seu questionamento: ele reconhece que jamais conseguiria reunir as duas metades, pelo menos não sozinho. A chegada 
de sua irmã Agathe abrirá caminho para uma nova etapa existencial. Pois Ulrich busca viver com Agathe como "num romance [...] numa espécie de parábola, no intuito de restituir o sentido maior da vida" (Müller-Funk, 1995, p.199, grifo nosso). A utopia do "outro estado" será, pois, um esforço de transpor para a prática aquilo que, ao longo de todo o primeiro volume, apresentou-se como autoexigência teórica. $\mathrm{O}$ reencontro com Agathe abre a Ulrich possibilidades concretas, e não mais teóricas, de uma nova forma de vida. Nesse sentido, é estratégico que ela esteja ausente no primeiro volume. Sua presença impõe outro ritmo à narrativa já que faz que o pensamento de Ulrich se desenvolva de uma nova maneira, mais direcionada para a ação - ou para um experimento em seu sentido pleno.

\section{O "outro estado"}

Com o reencontro entre os irmãos, o romance passa a encenar justamente a "outra história" que Musil reivindica na segunda parte do romance - uma história que não seja mais uma repetição inócua, e que justamente por isso envolverá seu autor numa intrincada rede de possibilidades. A escritura dessa "outra história" exige experiências que se passam num "outro estado" - a última utopia almejada por Ulrich, agora ao lado de Agathe. No plano inicial da obra, essas experiências aconteceriam ao longo do segundo volume. Dentre as passagens que integram a parte da obra que foi publicada em 1943, logo após a morte de Musil, o capítulo "Raios de luar durante o dia" ["Mondstrahlen bei Tage"] é o que tematiza mais de perto essas experiências. ${ }^{10}$ As mais intensas - como os capítulos "Suspiros de um dia de verão" ["Atemzüge eines Sommertags"] e "Viagem ao paraíso" [ "Reise ins Paradies"] - permaneceram inconclusas, pois era nelas que Musil trabalhava mais obstinadamente, inclusive no dia de sua morte. Ele se via diante do desafio de descrever, com sobriedade - já que a razão nunca é abolida por completo -, uma experiência quase absoluta, na qual sentir e refletir atingem praticamente o mesmo patamar, mas ainda um passo aquém de uma fusão mágica. Uma descrição mais detida desse estado encontra-se num ensaio de 1925, "Princípios para uma nova estética", no qual Musil (1978b, p.1137-54) afirma a existência de duas dimensões do espírito que se influenciam mutuamente, mas que não chegam a se mesclarem de fato. Uma delas seria a "normal", o modo pelo qual nos relacionamos com o mundo, com as pessoas e conduzimos nossa vida empírica. A outra dimensão, "historicamente menos verificável" é um "estado de amor", "de bondade, de desligamento do mundo, de contemplação e aproximação com Deus" (ibidem, p.1144) - uma experiência a que só temos acesso por meio da religião ou da mística. Contudo, é um estado passageiro - caso contrário, se transforma em patologia - e por isso pode ser aproximado de um estado poético. Uma vez que somente a arte consegue atingir uma simultaneidade constante entre experiência e reflexão, esse "estado de amor" descrito aqui obedece à mesma dinâmica que permeia a relação (de amor) de Ulrich e Agathe. 
Esse sentimento de "perda do fio narrativo", que atinge Ulrich de várias maneiras, já o acometia desde muito cedo, embora ele ainda não o percebesse: a impossibilidade de identificar-se com o pai o leva, na infância, a desejar ser menina. É ao ver a pequena Agathe vestida com um traje de festa que Ulrich tem um primeiro lampejo de senso de possibilidade. Mais do que uma tentativa de abandonar a rivalidade com o pai, ou de trilhar um caminho próprio, esse desejo será a primeira manifestação de um anelo de uma fusão entre os dois sexos, que se desdobra no futuro em seu amor pela irmã. Dessa forma, esse sentimento será, antes, uma relação de Ulrich consigo mesmo, um amor-próprio [Eigenliebe], uma tentativa inaugural de adquirir uma "qualidade" [Eigenschaft]. A associação entre os opostos amor e violência, imaginação e razão, masculino e feminino, necessita de uma união radical, um parentesco de sangue. Na verdade, ambos trazem em si uma parcela de feminino e masculino e precisam de uma complementação no outro. Esse desejo de superação e complementação, em que a parcela feminina restitui a plenitude ao ser masculino cindido, Musil retira do mito de Ísis e Osíris, e o redimensiona à luz da situação do indivíduo de seu tempo, privado de possibilidades de um encontro consigo mesmo. $\mathrm{O}$ anseio por um todo, por uma (re)união mística, está na origem do incesto.

Ulrich e Agathe não podem se encontrar como homem e mulher, porque essa relação se enquadraria no código de comportamento vigente no mundo onde acontece "sempre a mesma coisa". Trata-se, no entanto, do encontro entre dois seres que são privados de si próprios, que se ressentem de uma identidade e, assim, na versão moderna do mito, Ísis não tem condições de entregar a Osíris o que ela mesma não possui. A invenção de uma "outra história" é uma tarefa árdua, que leva aos limites do possível. E o leitor será advertido sobre a dimensão que essa história vem assumindo:

Quem, pelos sinais, ainda não tiver reconhecido o que acontecia aos irmãos, que largue esse relato, pois será descrita uma aventura que jamais poderá aprovar: uma viagem à beira do possível, passando [...] pelos perigos do impossível e antinatural: um caso limite, como Ulrich diria mais tarde, de validade limitada e especial... (Musil, 2006, p.803)

Caberia perguntar, no entanto, o que de fato perturba o leitor: se o incesto iminente ou a percepção de que fora iludido - pois o romance apenas parecia ter recuperado seu fio épico; na verdade, essa "viagem à beira do possível" é também a parábola da própria obra que se encaminha para um ponto de virada em relação à primeira parte. À medida que cresce a propensão à mística - nos capítulos que permaneceram inacabados -, Ulrich, o homem que passou todo o primeiro volume pensando, percebe que a vida se tornou "insuportável para seres pensantes", e que atingira um estágio em que sua alma "estava pronta para se entregar ao mundo com todos os sentidos" (Musil, 1978a, p.1093). Só que, para que possam atingi-lo de uma vez por todas, os irmãos devem se afastar de todos os vínculos que ainda mantêm com o mundo "real". Assim, eles abando- 
nam o idílico refúgio doméstico e partem rumo ao Sul, sem passaportes, como convém a dois "criminosos". ${ }^{11}$ Longe de casa e à beira-mar, tudo é novo, vasto e absoluto: "eles nada compreendiam nesse novo mundo, e tudo era como palavras de um poema" (Musil, 1978a, p.1651). Nota-se aqui que a figura de Moosbrugger representa uma antecipação do "outro estado", mas na forma de uma variante social deste: o impulso de dissolver toda a contradição do mundo em um ato criminoso e sua indissociação entre mundo interno e externo são similares à uma tendência coletiva para a "redenção" na guerra.

Como bem define Honold (1995, p.463-4), trata-se de uma encenação às avessas do pecado original: se, na bíblia, a expulsão do paraíso substitui sensualidade por conhecimento; no episódio do incesto é o conhecimento que os irmãos atingem por meio dos sentidos e da comunhão mística que se coloca como anátema entre eles. Mas Ulrich e Agathe sempre foram um único ser, por isso não podem se satisfazer com essa experiência. A magia do outro estado foi subvertida. Ela consistia em seu poder de suspender os princípios, na possibilidade de uma experiência que não poderia acontecer fora dele. No momento místico, o sujeito corre o risco de se diluir em nada. O mundo em que tudo era um sim se transforma em pura negatividade. À suspensão radical do tempo segue-se a dissolução completa da identidade, e a revolta contra a realidade, na origem do amor entre os irmãos, perde o sentido (Böhme, 1972, p.372).

Os capítulos inacabados dão pistas de que o próprio Ulrich viria a reconhecer seu equívoco: "Um amor pode nascer da teimosia, mas não pode consistir apenas de teimosia [...] não se pode viver apenas de negação" (Musil, 1978a, p.1463). Mas o reconhecimento do equívoco não apaga o fato de que ele o cometeu. Revolta e teimosia pertencem à esfera da violência; quando associadas ao amor, surge uma ligação falsa entre os dois princípios, na qual o amor se converte em seu polo oposto. E justamente Ulrich, que perseguia obstinadamente o ideal da exatidão, da ligação ideal entre os princípios, incorre no erro capital de colher o fruto da árvore proibida. No entanto, esse paradoxo constitui o sentido maior do romance de Musil, e mesmo a legitimação de seu inacabamento.

\section{$O$ romance possível}

A catástrofe de Ulrich e Agathe é também aquela que o romance não narra, mas anuncia nas reuniões da "Ação paralela", no julgamento de Moosbrugger - aquele que incarna o sonho de toda a humanidade - e em tantos outros episódios que parecem secundários diante do encontro entre os irmãos, mas que, na concepção circular da obra, representam de forma multívoca o caos espiritual de um mundo às vésperas de uma guerra que irrompe das "lacunas abertas pela expectativa de uma redenção" (Honold, 1995, p.147). O fato de a relação entre os irmãos se tornar grande tema do segundo volume, ou de que todo o panorama social da primeira parte seja reduzido à grande "viagem" que eles empreendem, não significa um desvio de propósito. Pois o "outro estado" nada mais é do que a parábola da guerra, ${ }^{12}$ da utopia de uma sociedade extática, 
ansiando pelo aparecimento de uma nova energia, que rompesse com as formas de existência constantes; enfim, com esse mundo em que sempre acontece a mesma coisa. Agathe e Ulrich pretendiam se lançar à morte, caso sua aventura malograsse. Mas em um mundo em que a morte passou a ser uma experiência em massa, em que as experiências mais subjetivas são filtradas pela linguagem corrente, um suicídio será apenas uma mera citação do desespero. A pena de morte foi uma forma de "objetivar" o crime de Moosbrugger. Musil se recusa a fazer o mesmo com Ulrich. Como puni-lo por tentar não mais ficar suspenso entre os princípios que custou tanto a reconhecer?

À impotência dos irmãos corresponde a do escritor, que não consegue dar fim à sua obra monumental ou definir o desfecho da aventura intelectual de seu herói. No entanto, é o fracasso da utopia pessoal de Ulrich e Agathe que permite a realização da utopia da literatura. Sua tentativa de união absoluta é uma representação radical das "múltiplas relações do ser humano consigo mesmo e com a natureza, que ainda não são puramente objetivas e talvez nunca o sejam, só se podem conceber como parábolas" (Musil, 2006, p.631). Se o autor permite que seu herói se entregue ao êxtase dos sentimentos, é porque sua busca atingiu um limite. E esse limite, ele o contrapõe à amplitude da parábola.

A constante possibilidade de recontextualização de uma obra que se pretende ensaística corrobora a ideia de que a realidade é apenas uma versão entre várias possíveis. Musil não concebe o ensaio apenas como tentativa; trata-se, antes, de "se atingir um objetivo dentro dos limites que ele mesmo impõe" (Bouveresse, 2001, p.376). Assim, o romance não almeja a utopia, e sim torna-se ela própria: ao adotar uma forma singular, mas numa linguagem clássica, ele nos faz experimentar a nossa própria realidade, só que de uma outra maneira. Das "lacunas entre catástrofe e redenção", a obra constrói uma "utopia do aqui e agora" (Arntzen, 1960, p.115) em que o universal é passível de ser transformado por meio do individual. E o porta-voz dessa utopia só poderia ser um personagem cujas qualidades mais flagrantes fossem o espírito ensaístico e o senso de possibilidade.

O homem sem qualidades é um dos romances do século XX que mais exigem "capacidade e desejo de abstração" de seus leitores - condições que Musil (1978b, p.1255) reivindica em "O escritor nos dias de hoje"- por representar, de forma plena, a impossibilidade tanto de uma existência organizada no tempo e no espaço quanto de uma recusa radical desses limites. Seu inacabamento é consequência direta dos princípios que ele mesmo difunde. A aventura literária de Musil, assim como a de Ulrich e Agathe, teve de chegar a seu termo - são os limites impostos pelo próprio objeto. Mas o espírito ensaístico que eles próprios legaram à literatura permite que a tarefa desta estenda-se ao infinito. 
1 No original: "Und wenn sie auch gewiß nicht für jeden Menschen und alle Welt ebenso empfanden wie für einander, so spürten sie doch den schönen Schatten des "Wie es wäre" davon auf ibr Herz fallen...".

2 Essa terceira parte foi publicada pela esposa de Musil, Martha, no ano seguinte à sua morte, sob o título "Obra póstuma" (Aus dem Nachlab). Ela se compunha dos vinte primeiros capítulos deste que seria o volume conclusivo do romance. Uma controversa edição, contendo a totalidade dos esboços referentes a essa última parte, foi publicada sob organização de Adolf Frisé em 1956 e reeditada, com modificações, em 1978. A tradução brasileira conta com os dois primeiros volumes e os capítulos publicados sob o título de Obra póstuma.

3 A esse respeito, ver Luft (1984, p.19ss).

4 São reflexões que Musil desenvolve em seu ensaio “Skizze der Erkenntnis des Dichters” ("Esboço sobre o conhecimento do escritor"), de 1918 (Musil, 1978b, p.1025-30).

$5 \mathrm{Na}$ origem do substantivo Eigenschaft está o adjetivo eigen, que significa "próprio", "específico", "característico". Não há, portanto, uma conotação moral, como a tradução por "qualidade" em português pode dar a entender.

6 Como ocorre com outras passagens emblemáticas da obra, o episódio do julgamento será a parábola da própria composição ensaística do romance. Assim como Ulrich, dentro de seu espírito ensaístico, atribui importância maior ao processo de julgamento e a todas as suas implicações do que à sentença final, o inacabamento da obra não compromete seu potencial ético-estético mas, ao contrário, o ratifica. Valeria lembrar ainda que G. Lukács (1971, p.31) recorre à mesma imagem do julgamento em seu conhecido escrito sobre o ensaio, no sentido de ilustrar o caráter inacabado desse tipo de texto: "O ensaio é um tribunal onde o essencial e decisivo não é o julgamento, mas sim o processo de julgar” (tradução nossa).

7 Chardin (1998, p.251) observa que, ao desistir de fazer de seu protagonista um literato, Musil evita que também a literatura se torne uma atividade "especializada", permitindo que ela se estenda a todos os domínios da existência.

8 A imagem das "duas árvores da vida”, uma evidente alusão ao Gênesis (2:9), sintetiza uma profícua rede de referências bíblicas que fazem do romance a "parábola" de uma sociedade à beira da "queda": desde a "crucificação" pública de Moosbrugger e a iniciativa da "Ação paralela", até o encontro entre Agathe e Ulrich, vivenciado como uma experiência definitiva de conhecimento e morte, são várias as tentativas de redenção, coletiva ou pessoal, que culminariam no "Juízo Final” da Primeira Grande Guerra.

9 Aqui modificamos a tradução brasileira, que equivocadamente traduz a palavra Gleichnis (parábola, símile, comparação) por "símbolo" - também em outras passagens do romance. Extrapolaria os limites deste artigo discutir a incoveniência dessa escolha; caberia apenas ressaltar que o símbolo - "Symbol" em alemão - supõe uma vinculação natural e imediata entre a imagem e seu significado, o que por si só contradiria o processo de conhecimento da personagem, tal como pretendido por Musil.

10 Este capítulo faz parte do conjunto que foi publicado sob o título Obra póstuma (Aus dem Nachlaß) e que também integra a tradução brasileira. As citações referentes aos capítulos inacabados foram retiradas do segundo volume da edição alemã (Musil, 1978a). 
11 Como vem aludido no título da terceira parte da obra: "Rumo ao reino dos mil anos (Os criminosos)". Podemos ainda insistir na referência bíblica, pois logo antes de decidirem partir, Ulrich e Agathe viviam numa situação idílica no jardim doméstico, onde acontecem suas primeiras experiências do "outro estado". Na passagem a seguir, o "fruto" será o elemento que indica uma nova forma de conhecimento, que associa a percepção da realidade à imprecisão dos sentimentos, ou que indissocia o mundo externo do interno: "Pois em tal estado, a palavra carece de fio e o fruto fica no galho, apesar de posto na boca: esse é provavelmente o primeiro segredo da mística diurna" (Musil, 2006, p.1146-7).

12 Como se pode ler numa anotação deixada por Musil (1978a, p.1932/3), e que integra a parte inacabada do romance: “Guerra é o mesmo que o. e. [outro estado], só que misturada ao mal $[\ldots]$ uma fuga da paz".

\section{Referências}

ADORNO, T. W. Notas de Literatura I. Trad. Jorge Almeida. São Paulo: Duas Cidades $/ 34,2003$.

ALBERTSEN, E. Ratio und "Mystik» im Werk Robert Musils. Münch: Nymphenberger, 1997.

ARNTZEN, H. Der moderne deutsche Roman. München: Winkler, 1960.

. Musil. Kommentar zum Roman >>Der Mann obne Eigenschaften<<. Münch: Winkler, 1982.

BLANCHOT, M. Musil. In: __. Le livre a venir. Paris: Gallimard, 1986.

BÖHME, H. Anomie und Entfremdung. literatursoziologie Untersuchungen zu den Essays Robert Musils und zu seinem Roman "Der Mann obne Eigenschaften". Kronberg: Scriptor, 1972.

BOUVERESSE, J. La voie de l'âme et les chemins de l'esprit. Dix études sur Robert Musil. Paris: Seuil, 2001.

CHARDIN, P. Musil et la littérature européenne. Paris: PUF, 1998.

FRANK, M. L'absence de qualités à la lumière de l'épistémologie, de l'esthétique et de la mythologie. Revue d'Esthétique, Toulose, n.9, p.105-18, 1985.

HONOLD, A. Die Stadt und der Krieg. Raum- und Zeitkonstruktion in Robert Musils Roman >>Der Mann ohne Eigenschaften<<. Münch: Wilhelm Fink, 1995.

LUKÁCS, G. Die Seele und die Formen. Neuwied /Berlin: Luchterhand, 1971.

. Teoria do romance. Trad. José Marcos M. de Macedo. São Paulo: Duas Cidades $/ 34,2000$.

LUFT, D. Robert Musil and the Crisis of the European Culture. Berkeley; Los Angeles / California: University of California Press, 1984.

MÜLLER-FUNK, W. Erfahrung und Experiment. Studien zur Theorie und Geschichte des Essayismus. Berlin: Akademie Verlag, 1995.

MUSIL, R. Der Mann obne Eigenschaften. Reinbeck b. Hamburg: Rowohlt, 1978a. 2v. . Prosa und Stücke, Kleine Prosa, Aphorismen, autobiographisches Essays und Reden, Kritik. Reinbeck b. Hamburg: Rowohlt, 1978b. 
MUSIL, R. O homem sem qualidades. Trad. Lya Luft e Carlos Abbenseth. Rio de Janeiro: Nova Fronteira, 2006.

RENNER, R. Die postmoderne Konstellation. Theorie, Text und Kunst im Ausgang der Moderne. Freiburg: Rombach, 1989.

VObKAMP, W. Utopie als Antwort auf Geschichte. Zur Typologie literarischer Utopien in der Neuzeit. In: EGGERT, H.; SCHERPE, K. Geschichte als Literatur. Formen und Grenzen der Repräsentation von Vergangenheit. Stuttgart: F. B. Metzlersche, 1990. p.273-95.

WIEGMANN, H. Musils Utopiebegriff und seine literaturtheoretischen Konsequenzen. In: UEDING, G. Literatur ist Utopie. Fankfurt a. M.: Suhrkamp, 1978. p.309-34.

WOLF, N. Kakanien als Gesellschaftskonstruktion. Robert Musils Sozioanalyse des 20. Jahrhunderts. Vien: Böhlau, 2011.

RESUMO - O presente artigo aborda o romance O homem sem qualidades, de Robert Musil, como uma obra que adota pontualmente o princípio fundamental da literatura: a ampliação das possibilidades, a partir da representação de uma experiência real de vida. Ao focalizarmos alguns dos aspectos centrais da composição do romance - o ensaísmo, a representação da realidade como ficção, o enredamento entre a forma narrativa e a reflexão sobre suas possibilidades - procuramos mostrar de que modo Musil procurou tornar a forma romanesca receptiva para novos conteúdos. Seu propósito era de escrever um romance condizente com as condições históricas de seu tempo e que também acenasse com uma nova forma de vida, na qual as instâncias do intelecto e do sentimento, ou da ciência e da arte, fossem complementares e não antagônicas.

PALAVRAS-CHAVE: Robert Musil, Romance moderno, Ensaísmo, Forma literária, Literatura austríaca.

ABSTRACT - This article deals with the novel Der Mann obne Eigenschaften, by Robert Musil, as a work that accurately adopts a basal principle in literature, namely, the enhancement of possibilities stemming from the representation of real life experiences. Certain aspects of the book are emphasizes - e.g., essayism; the representation of reality as fiction; the entanglement between the narrative format and reflections on its possibilities - as we attempt to show how Musil tried to make the novel format receptive to new contents. His purpose was to write a novel according to the historical conditions of his time and that also alluded to a new kind of life in which the realms of intellect and sentiment, or science and art, are complementary and not antagonistic.

KEYWORDS: Robert Musil, Modern novel, Essayism, Literary form, Austrian literature.

Érica Gonçalves de Castro é pós-doutoranda em Filosofia na Faculdade de Filosofia, Letras e Ciências Humanas da USP. Doutorado em Literatura Alemã (FFLCH-USP). Pós-doutorado em Teoria Literária e Literatura Comparada (FFLCH-USP).

@ - ericastro@yahoo.com

Recebido em 23.11.2015 e aceito em 21.2.2016.

I Faculdade de Filosofia, Letras e Ciências Humanas, Universidade de São Paulo, São Paulo / São Paulo, Brasil. 